\title{
Unveiling Madeira's destination image and representations through Virtual Museum of Tourism (MUVITUR) ${ }^{\circledR}$
}

https://doi.org/10.2478/ejthr-2020-0008

received December 12, 2019; accepted April 10, 2020

\begin{abstract}
This article intends to demonstrate the importance of the existence of an aggregating platform for digital content, as is the case of MUVITUR - Virtual Museum of Tourism, for the research in tourism and also to assess its potential.
\end{abstract}

Aiming to track the history of Madeira's destination image, this paper also searches to contribute to the study of the 'Atlantic Pearl' distinctive features for promotional purposes throughout seventy years.

For this purpose, the authors did an integrated search aiming to find and study the retrieved results of promotional visual materials edited during the twentieth century, focusing on Madeira Island, as an example of the potentialities of the Muvitur database.

With this research, we can conclude that tourism marketing strategies seem to have succeeded to consolidate Madeira's destination image focused on its distinctiveness. Digital objects gathered in such searchable thematic databases, with a diversity of content providers, can play a crucial role in the history of tourism and leisure, allowing us, at the same time, to know how Madeira represented the destination for promotional aims.

Keywords: MUVITUR; Madeira Island; History of tourism; Tourism promotion; Destination image; Representations

\footnotetext{
*Corresponding author: Maria José Aurindo, Escola Superior de Hotelaria e Turismo do Estoril , Avenida Condes de Barcelona nํ 808, 2769-510 Estoril, Portugal; maria.aurindo@eshte.pt, ORCID: https:// orcid.org/0000-0003-4794-8950

Conceição Machado, Escola Superior de Hotelaria e Turismo do Estoril, Avenida Condes de Barcelona nㅇ 808, 2769-510, Portugal; conceicao.machado@eshte.pt
}

\section{Introduction}

Tourism communication has long been vital for destination attractiveness and has been a source of numerous conceptual approaches to its better understanding going from Dann's 'language of tourism' (Dann, 1996) to Urry's consuming places and tourist gaze (Urry, 1995, 2002).

Regarding tourism destination branding imagery as symbolic spaces for tourism representations of places and cultures, we may find attention-grabbing features used to depict the displayed destinations to encourage their visitability, even before the actual visiting experience.

The image (the centre of visual culture) has a remarkable ability to index or reference things, people, places, and events in the real world, which appear as palpable, irreducible and unquestionable, constituting essential requirements in tourist communication. Evans and Hall (1999, p. 4) also point out that while it is true that an impressive power of meaning is inherent in the image, we should not neglect the observer's ability to interpret the emanating meanings.

Although not exclusively, but consistently, Madeira's international recognition produced and conveyed consistent promotional images over decades leading to what can already be considered a mature destination.

Portuguese tourism history has in Madeira's one of its embryonic tourism destinations allowing us to tail its related representational imagery through time.

Cultural features linked to authenticity and exaltation of nature (from its health benefits to the pleasure given by the experience) happened to be the primary two mainstays of the representational discourse and branding strategy over time.

These are recognizable features we may find in guides' narratives, travel literature or promotional materials, but even more strongly in eye-catching visual culture imagery. 


\section{The Imagery Discourse of the Tourist Destination}

It is hard to imagine tourism without the creative use of tempting as well as restrictive imaginaries of both people and places. Tourism imaginaries are socially transmitted representational assemblages that interact with people's imaginings and are used as meaning-making and world-shaping devices in tourism and beyond (Salazar, 2016, p. 456).

Although already a subject matter of interest, the study of the image has first grown relevance in its association with psychology (Jafari, 2000, p. 295-296). In tourism research, it began to gain relevance in the 1960s and particularly the 1970s, increasingly associated with studies in the field of marketing and, progressively, by other disciplines such as anthropology, sociology or geography, among others. However, as the author also stresses, it remains an underexplored area of inquiry.

However, in recent years, research on the image of the tourist destination has been changing its relative importance in the study of the destination brand, being one of its main dimensions but not the only one.

While with different approaches, the common point seems to be the importance it has in the purchase decision and the degree of satisfaction with it, as well as the relevance that destinations see in the construction and delivery of images that are favourable to them (Pike, 2002).

Despite the already broad conceptual and methodological framework within the research on the image of tourist destinations (Gallarza, Saura \& García, 2002), as for the study of tourism imaginaries and their transmission (Salazar, 2012), systematic documentary sources are often lacking in order to illustrate assertively and representatively the imaginings and their change over time, sometimes resorting to a small and sparse number of pieces of evidence.

Blain, Levy and Ritchie (2005, p. 331) define place branding as 'the marketing activities (1) that support the creation of a name, symbol, logo, wordmark or other graphic that both identify and differentiate a destination; (2) that convey the promise of a memorable travel experience that is uniquely associated with the destination; and (3) that serve to consolidate and reinforce the recollection of pleasurable memories of the destination experience, all with the intended purpose of creating an image that influences consumers' decisions to visit the destination in question, as opposed to an alternative one.' [italics in original].
Looking at the author's last definition's emphasis, and even if the concept now presented is quite recent, especially when tracing back the promotional history of older destinations, it seems to reinforce what was already the effort to highlight what was the destination 'product to be' at the time of the production of the visual materials.

There is already a broad acknowledgement of how consumption, place and identity often come along together when talking about tourism destination image. This is true both when we look at institutional players, but also and increasingly more when non-institutional, mainly commercial players, strive to identify, create and promote identity markers.

Tourism discourses were also muscularly used by nation's marketing responsible institutions for tourism promotion (formerly called tourism propaganda) to construct and display the official narratives when representing national and regional identities and while responding to social, economic, cultural and political musts.

These nation-branding campaigns are active symbolic spaces of identity production, designed to induce potential visitors on a discourse of 'who we are' so that we deserve a visit, but also and importantly to foster the sense of national belonging.

Within the tourism promotional paraphernalia, there are two components that we would like to highlight for what we believe to be their weight for the output message: image and slogans.

It is easy to understand that the construction of tourist visual discourse contributes significantly to limiting or shaping individuals' perceptions of the characteristics of any place they want to visit. We found that 'the image can conjure up an entire site, region, and structure of experience by representing only a fragment (say, a palm tree or a local in costume), and the image can also address viewers directly by virtue of a mimetic visual language.' (Crouch \& Lübbren, 2003, p. 5).

\section{Tourism Research and the History of Tourism}

Given the vital role of travel and tourism in the contemporary world, the interest in their study seems to have taken its first steps in the second half of the nineteenth century, having seen a definite increase in the first decades of the twentieth century, spanning a vast set of topics. 'In the history of tourism, it has been quite common to analyse ways of presenting data on tourist destinations, local cultures and representations of past tourists at specific times 
and contexts. Topics have varied a great deal: from the colonial or imperial views of travellers to their views on local cultures or cultural presentations and from tourism propaganda and exhibition to the curiosities or meetings of locals and foreigners.' (Jafari \& Xiao, 2016, p. 428)

Research trends in the history of tourism, not exclusively developed by historians, have seen new trends also emerge from the approach traditionally associated with tourism studies, with a significant increase in the early twentieth century, with new approaches, themes and spaces, notably in the emerging digital humanities.

We understand that there are multiple and relevant objects, bibliographic and documentary sources that are yet to be systematized, scattered throughout various archives, libraries and museums, owned by private collectors or still offered in the collectable market. Despite the relative newness that tourism represents for many historians, this condition undoubtedly contributes to the still reduced amount of thematic research on local, regional, national and international tourism history.

Tourism research, particularly the history of tourism research, rests on the availability of trusted sources. In the visual sphere, this longitudinal type of analysis, following the 'life' of a destination image is particularly difficult without jigging in between a considerable number of sources (institutions, catalogues, locations, etc.). It sometimes represents unsurmountable time and money resources, particularly in an era where there is an assessment of the amount of published research, which is not compatible with the lengthy research endeavours that this dispersion of materials requires of the researcher.

We can therefore easily understand that from a material point of view, and given the ever-evolving objects that bear witness to the practices that occupy those interested in the history of tourism, the history of tourist destinations can more easily be pursued by sharing and aggregating information scattered in local, regional and national collections.

Despite the tendency for collections to be focused on local, regional and national realities, some objects refer to different geographical contexts that are sometimes even no longer available at their publishing, production or promotion institutions and locations.

Besides, many of the relevant materials for telling the history of tourism, by the very nature of the phenomenon, will have been produced in one place, but eventually transported and stored and preserved in a completely different place remote from its conception and production site.

If we can realize the importance of these iconographic documents in the transmission of information for various purposes, we must also understand their relevance in the reconstitution and consequent interpretation and historical-cultural contextualization in a given society.

However, the fate of these promotional materials as perennial artefacts is frequently the garbage, as soon as they seem to have finished playing their function. This ephemeral characteristic common to most promotional materials makes it extremely important to find ways of preserving and valuing them as historical testimonies.

\section{Virtual Museum of Tourism}

Estoril Higher School of Hospitality and Tourism - ESHTE (http://www.eshte.pt) publicly presented the Virtual Museum of Tourism - MUVITUR (http://muvitur.eshte.pt/) last June 2016. The main goal of the project is to be able to musealize the history of tourism activity using a virtual interface that already allows online browsing in an essential collection of objects related to tourism, hotels, leisure and restaurants (books, brochures, posters, postcards and many others) and allows for engaging virtual experiences.

Finding and discovering information and documents has always been time-consuming for researchers and having online hubs that smooth the process is just one of the potential benefits found using its online catalogue.

Like other projects, MUVITUR fits in the massive trend of digitization and provision of access to digital objects and the reuse of digital content that is a crucial part of the Digital Agenda for Europe (Aurindo \& Machado, 2016, p. 304). The Virtual Museum of Tourism aims to increase the availability and preservation of electronic information resources available throughout the world, while establishing a research infrastructure and strengthening e-learning environments, in this case, curated to blossom the whole tourism-related domains of intervention.

Since higher education institutions are the mainstay of research par excellence, their museums cannot fail to reflect this function, whether in the themes presented by exhibitions or other programming or in all aspects of museum practice. MUVITUR intends to promote studies, inventories and research from a multidisciplinary perspective, with a view to a better knowledge of the history of tourism, leisure and hospitality.

MUVITUR presents as one of its main aims the enlargement of the aggregator hub created for heritage guardians, giving open access to their collections, potentiating the preservation of otherwise sometimes less valued objects and documents, helping to foster digitization projects and 
nourishing resources with metadata that might enhance and enrich the possibilities for information retrieval.

\section{Methodology}

The Virtual Museum of Tourism catalogue comprehends a database management system of digital and digitized objects afforded by several providers, ranging from libraries to museums, both public and private, national, regional and international, embracing materials within themes of tourism, hospitality and leisure. Therefore, the available database of digital objects aims wide-ranging research on a topic or place, so that through MUVITUR, everyone may access digital resources for tourism, hospitality and leisure history for the potential broadest variety of purposes.

So, to make this study possible, despite the germination phase of the MUVITUR catalogue, designed to showcase its potential in information retrieval, currently presenting contents from a limited number of content providers, both national and international, it allowed us to find about a hundred results of digital objects related to Madeira island destination. The results retrieved amongst the digital object records accessible in full digital format, using keywords, came from three different content providers whose metadata has been aggregated on MUVITUR database to allow an integrated search. So, even if there is a document in one of the providers' catalogue, but it is still not digitally available, the metadata will wait for its digitization for selection and the subsequent migration to integrate the MUVITUR database.

A closer look at the returned results from this search allows us to find the presence of digital objects representative of various collections: postcards, posters, leaflets, periodicals or monographs. The focus of the analysis rested on the materials edited by institutional entities while observing the set of available materials, so that their framing may be possible.

It should be noted here that the island of Porto Santo, Selvagens and Desertas were wittingly not included in this analysis, due to the small number of digital objects available in the MUVITUR catalogue, and since these were always distinctive destinations of the Archipelago, each one deserving its attention in what concerns their promotional destinations imaginaries.

\section{Results}

\subsection{The Pearl of the Atlantic: From Therapeu- tical Sanatorium to a Tropical Resort}

From an early age, due to its geographical position in a strategic intercontinental maritime route crossroads and climatic excellence with low thermal ranges and mild temperatures, Madeira Island has been attributed health properties and therapeutic effects for the cure of lung diseases and, in particular, for tuberculosis.

Throughout the 19th century, many elected the island of Madeira on account of its climate's therapeutic virtues, frequently commended in both medical guides and travel literature for its climate, hospitality and the comfort of its farms (some of them later replaced by hotel establishments).

Visited by many doctors (mainly English) and notable personalities, politicians, members of the European royal houses, intellectuals, poets and writers, the qualities of Madeira as a therapeutic tourist destination, coined its title as 'natural sanatorium' and relied on the increase in Atlantic navigation.

The 'Pearl of the Atlantic' (Figure 1) was gaining importance within the context of the recommended healing resorts in Europe. A cycle of royal and imperial stays that indelibly marked the history and evolution of Madeira's tourism consecrated the reputation that Madeira enjoyed among clinicians of the time (Pina, 1991, p. 11)

The image and slogans used over time are newsworthy as they institute brand identity, as shown by the following digital reproductions issued by Madeira's Commercial Bureau (London) 'Modern Eden' monograph title and slogan advertisement (Figure 2). That conveyed already a

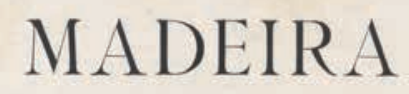

THE PEARL OF THE ATLANTIC

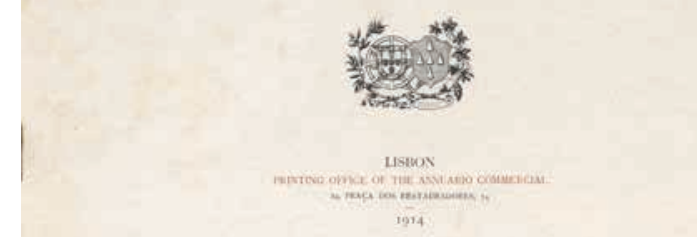

Figure 1: First page of a monograph published in 1914. Provider: Celestino Domingues Library 


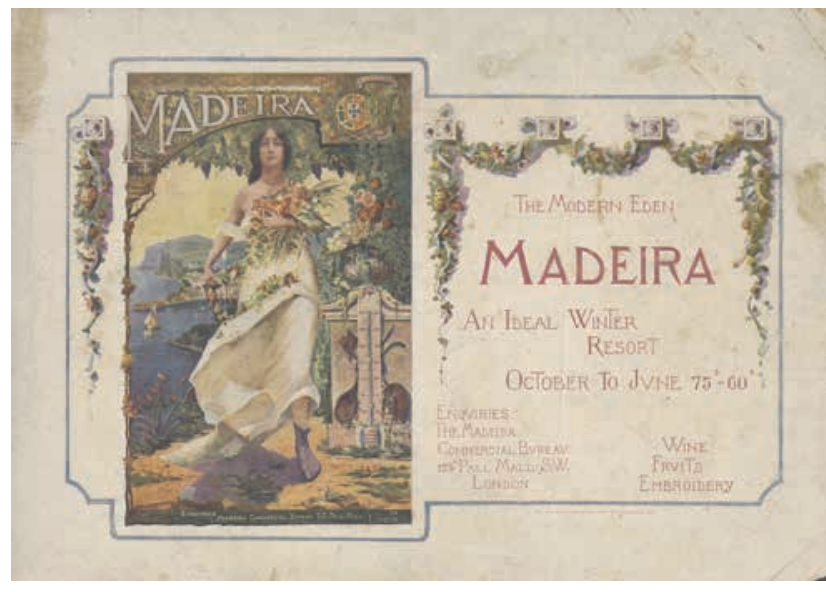

Figure 2: Cover of a monograph published in 1914. Provider: Celestino Domingues Library

slice of the imagery we happen to find conveyed through visual and textual promotional materials of Madeira destination, calling up weather and landscape, elements related to spring.

Due to the European political context, Madeira eventually ended up benefiting from restrained access to the therapeutic resorts of southern France and Italy, which forced the diversion of maritime flows to the island, which included the English, Germans and Russians (Baptista, 2005, p. 38).

The development of various industries (wine, tropical fruits and flowers, withes, embroidery), the development of commerce as well as the creation of hotel infrastructures owe a lot to the English and German entrepreneurial initiative, being the Reid's Hotel, inaugurated in 1891 (Baptista, 2005, p. 39), the iconic image of the Madeiran hotel industry.

Sailboats and ocean liners that crossed oceans before the opening of the Suez Canal (1869), called at its port and unsurprisingly heralded Madeira as the most famous national pioneer tourist destination for international visitors, making the transit passenger one of the most relevant categories of tourists visiting Madeira (Silva, 1985, p. 8).

The 1930s and the economic depression promoted Madeira as a retreat for many wealthy Europeans seeking to stay away from the conflict zones, with a higher representation of the English and German visitors. In November of 1930, the first meeting of the Tourism Commission was held to study the necessary measures for the development and advertising of local tourism (Silva, 1985, p. 11), since tourism was already considered a significant bet for the economy of the island. With more and more travel reports and guides, visits from royalty celebrities and intellectuals, from winter tourist resort, Madeira inevitably becomes gradually as a year-round resort. Silva also

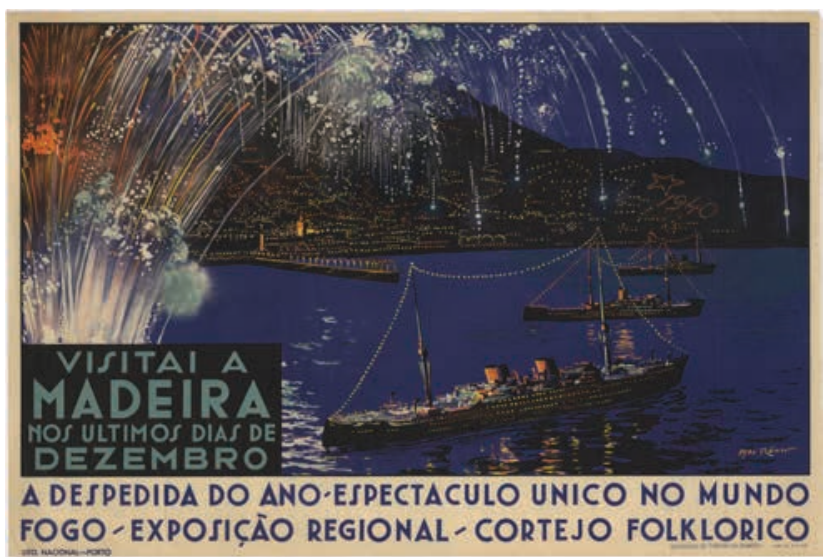

Figure 3: Poster $(62$ × $92 \mathrm{~cm})$ published in 1939. Provider: National Library of Portugal

stresses that in 1932 the 'Town Party Commission' was set up to plan the holiday season and in 1936 the Madeira Tourism Delegation was created under the Ministry of Home Affairs, which was responsible for the development of the local tourism policy at the local level in terms of infrastructure and advertising.

Leisure amusements, although not yet abundant, were already noteworthy in various accounts of writers and travellers, and some cases were already part of the tourist destination promotional appeal. Also, the development of the road network has made it possible to undertake a growing number of excursions to many points of interest, expanding the leisure activities available for the visitors.

Amongst the entertainment activities mentioned by Koebel (1909, pp. 178-186) there were already the kite flying, playing off the 'machete', visiting the theatre, cinematograph, carnivals of Funchal or the attention given to fire engines from the streets and balconies. We may here notice the promotion poster invitation for the New Year's Eve celebration in Madeira, with the slogan 'Visit Madeira in the last days of December' reproduced below (Figure 3).

It is common to find New Year's Eve celebrations as a notable event image used for tourism promotion purposes by different kind of tourism agents, along with the whole promotion communication history of Madeira, as shown by a variety of digital objects (poster, leaflet, hotel luggage tag, badge) found in MUVITUR database (Figures 4, 5 and 6).

Gradually, the port of Funchal became less sought by ocean liners, first because of the greater autonomy of maritime transport brought by the introduction of coal, now less dependent on the trade winds, and later to the lack of efficient port infrastructures indispensable to commercial navigation. This trend was, even more, accentuated 


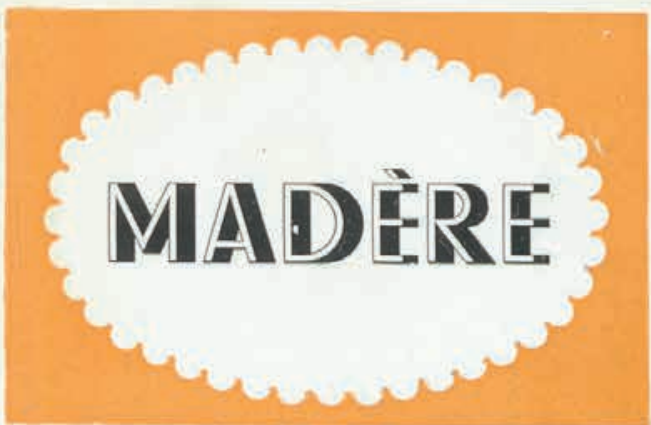

'archipel formé par Madère, Porto Santo et les Desertas, ajoute au Portugal une province insulaire, qui lui ajoute au Portugal une province insulaire, qui lui lun des jeyaux de dectere Pun des joyaux de son empire. Madere $(267.000$ hab. au large des cotes marocaines, est a $925 \mathrm{~km}$ sud-ouest de donne l'illusion d'un continent aux paysages infiniment variés.

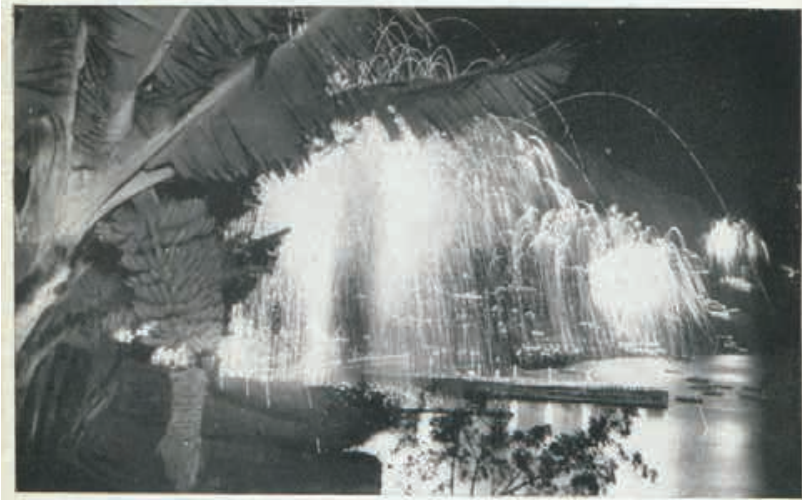

FUNCHAL, LA NUIT DE ST-SYLVESTRE - LES GRANOS FEUX D'ARTIFICE

L'exubérance de sa végétation, ses jardins tropicaux, la grandeur, la beauté de ses sites montagnards où la mer la grandeur, la beaté de ses sites montagnates où la mer apparait au bout de chaque valle, Pincomparabic douceur de son clinat en font un sejour délicicux en toute saison. Baignec par le galf-strcam, Madere ignore les rigueurs du froid ch paver comme la grosse chaleur deté. Sa temperature va te cnsoleilles et sans vent. labsence de toute poussiere sur les routes paves de lave, la pureté de Tair, le calme et la paix qu'on y respire, Tamenite de la population, tout concourt a lagrement du touriste de passage comme a celui du résidant Terre d'origine volcanique, dont le haut massif central dépasse $1.800 \mathrm{~m}$ d'altitude, son sol merveilleusement fertile produit un vin génereux et célébre; les arbres, les fleurs, les fruits du monde entier y croissent. Les filles de sez montagne passent a juste titre pour les plus fines brodeuses du monde.

\section{PORTUGAL}

Figure 4: Leaflet $(22 \times 30 \mathrm{~cm})$ published in the sixties. Provider: Documentation Centre of the Estoril Higher School of Hospitality and Tourism

during the Second World War. Besides the commercial navigation, the regular and tourist careers suffered a considerable fall in tourist flows in the port of Funchal. This situation justified the demise or downgrading of Madeiran hotels, the end or reconversion of the old farms (as they were acknowledged), or the decommissioning of Funchal

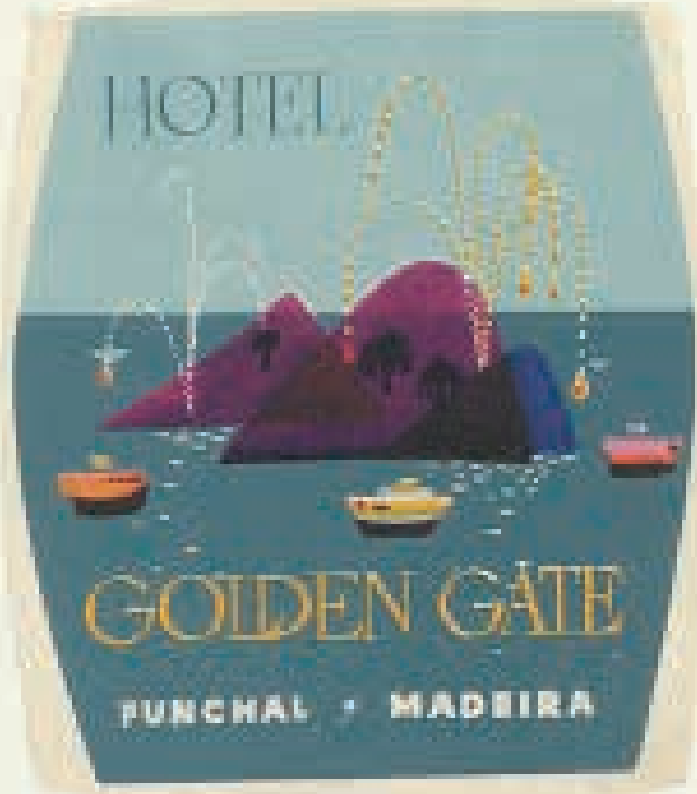

Figure 5: Luggage tag $(11 \times 9 \mathrm{~cm})$ published in the fifties. Provider: Documentation Centre of the Estoril Higher School of Hospitality and Tourism

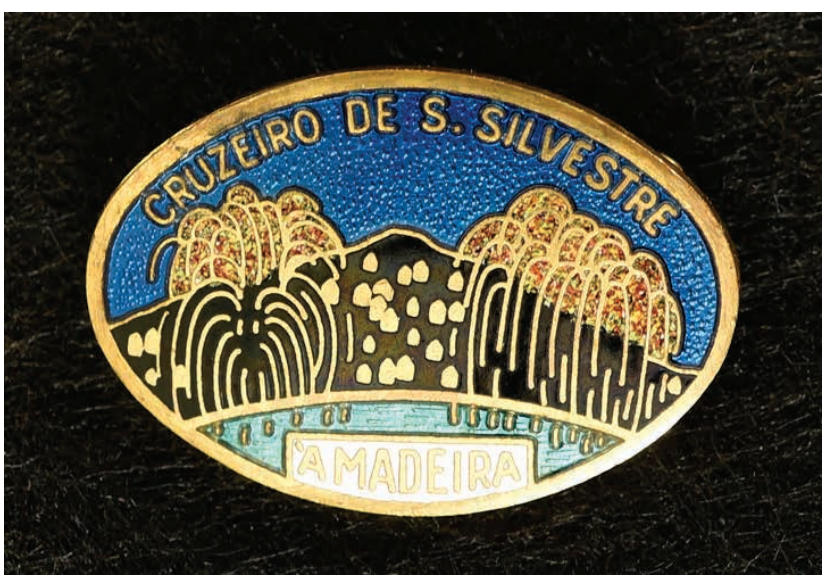

Figure 6: Metal badge $(1.9 \times 2.7 \mathrm{~cm})$ dated from 1962. Provider: Documentation Centre of the Estoril Higher School of Hospitality and Tourism

railway since their maintenance was no longer profitable. In its turn, the facilitation of air transport, while restraining maritime traffic in the port of Funchal gave a boost to the tourism industry of Madeira. (Silva, 1985, p. 7; Baptista, 2005, p. 40).

Tourist resorts such as the Canary Islands increasingly rival 'The island of health', Madeira, namely in terms of the population infrastructure and tourism services offered (Branco, 1936, p. 4). 
Despite its relatively late development, commercial aviation in Madeira, and its correlated fight against insularity, truly begins in 1949 with the Aquila Airways flying boats regular careers between Southampton, Lisbon and Funchal maintained until 1958. Aquila Airways, the only company with headquarters in England, Hamble, founded in 1947, equipped exclusively with seaplanes, was used predominantly for the service of an aerial bridge at the end of World War II.

As noted by Paulino and Silva (2000, p. 63), the end of the air bridge in 1948/49 winter forced the company to look for new services and, above all, destinations that could be operated by seaplanes, as was its purpose. Moreover, as it turned out, the first regular destination turned out to be Madeira Island, sought by many English tourists and eager to break its isolation through direct air links with Lisbon.

Aquila Airways promotional materials (Figures 7, 8 and 9) made it easy to recall the tourism communication effort conducted at the time, where we may find already most of the elements that were for the communication of the tourist destination (from weather and accessibility

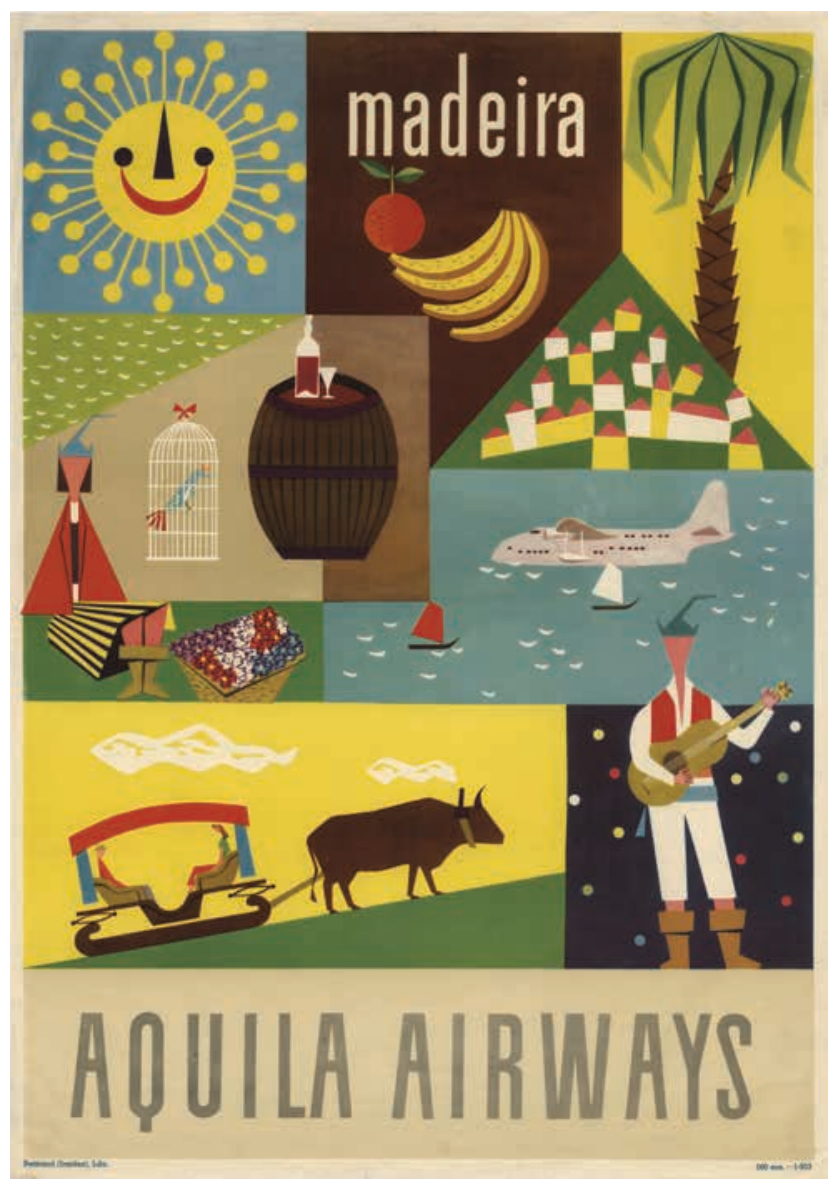

Figure 7: Poster $(100 \times 70 \mathrm{~cm})$ published in 1953. Provider: National Library of Portugal

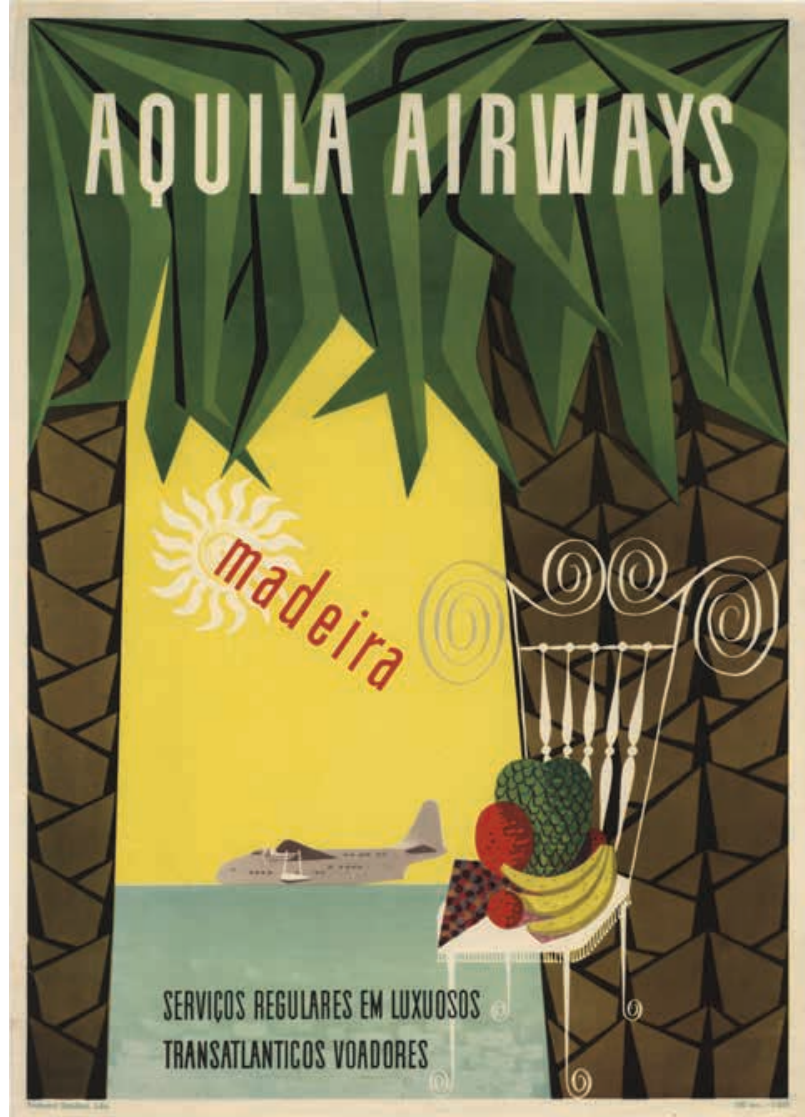

Figure 8: Poster $(100 \times 70 \mathrm{~cm})$ published in 1953. Provider: National Library of Portugal

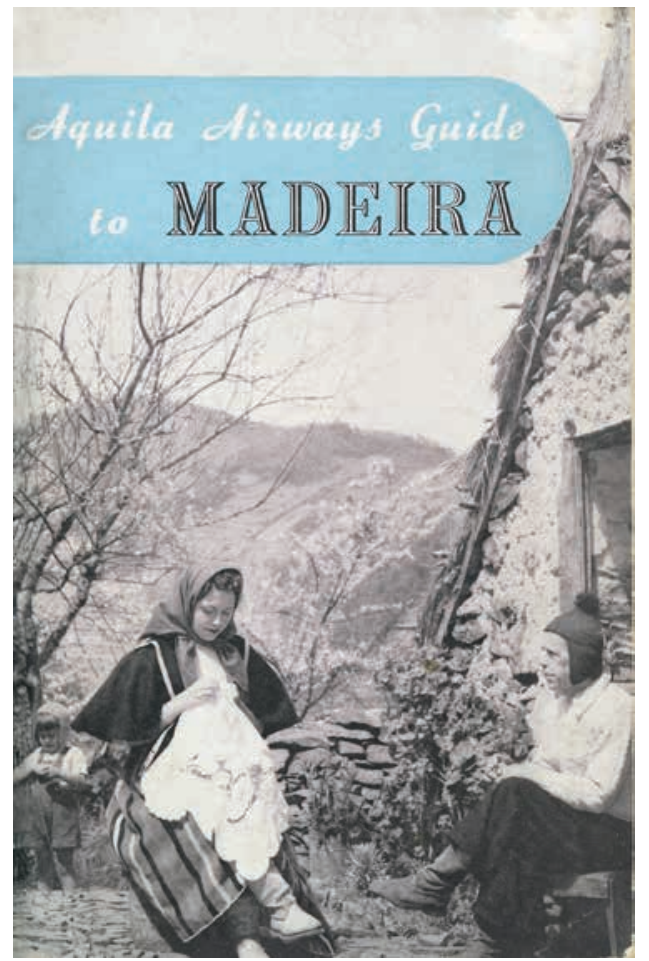

Figure 9: Guide published in 1958. Provider: Celestino Domingues Library 
to those that were the products chosen to enhance the natural and cultural landscape of the island).

It was the boost of the shipping and later the aviation companies operating for sale of goods and passenger transportation that were consolidating the regular routes to this archipelago to get clear responsibilities for editing promotional materials (now with clear commercial intentions) and, therefore, to shape the visual tourist imagery of Madeira destination.

With Porto Santo's International Airport (1960) and finally Madeira's International Airport (1964), whose runway of 2784 meters took a long time to become a reality (2000), the destination became recognized as an intercontinental airport.

It was also from the 1960s onwards that hotel capacity began to increase in an expressive manner meeting the demand allowed by the increase in airport capacity for other plane tonnages and answering what the beginning of the massification of tourism was.

This period was a time where we can find an apparent reinforcement of nature and popular culture mishmash, putting the performance of tradition in context as a seal of the advertised 'authentic' experience where

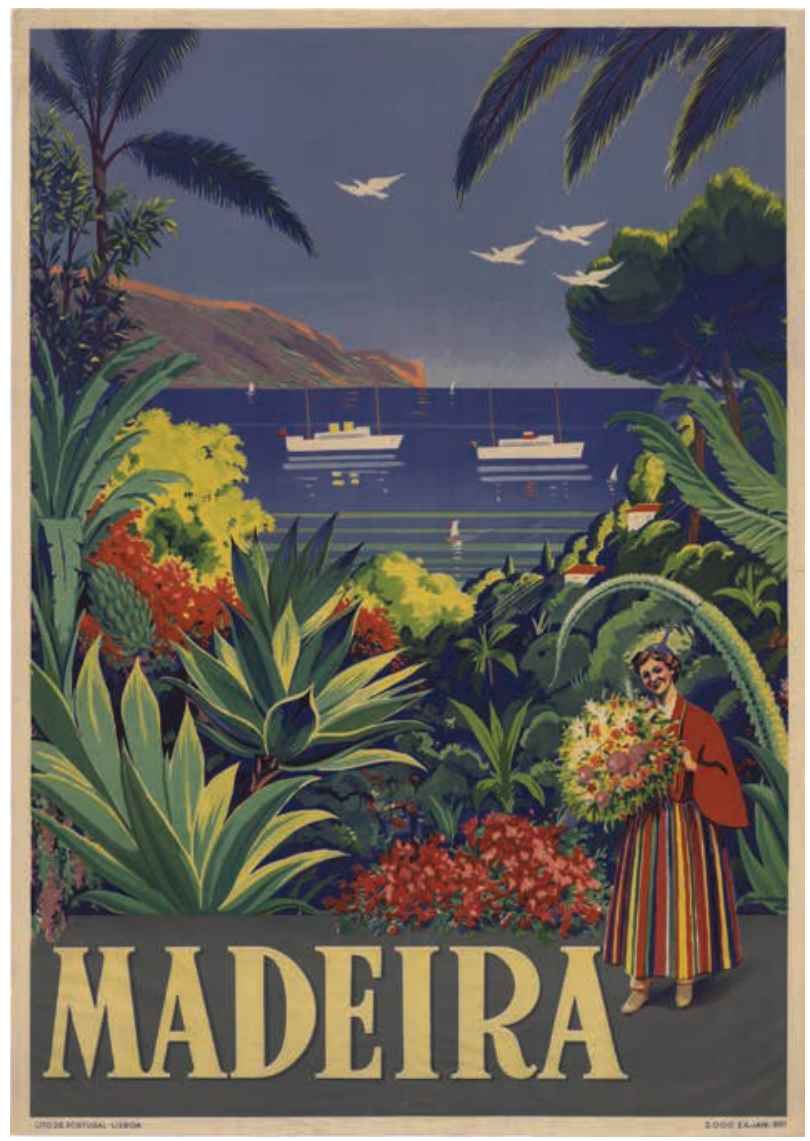

Figure 10: Poster $(100 \times 70 \mathrm{~cm})$, published in 1951. Provider: National Library of Portugal the visitor would quickly come across the identity practices and symbols. Together, the place and the landscape gained more weight, which offered a set of fundamental specific features, almost being confused with promotional images of paradise-like tropical destinations (Figures 10, 11 and 12).

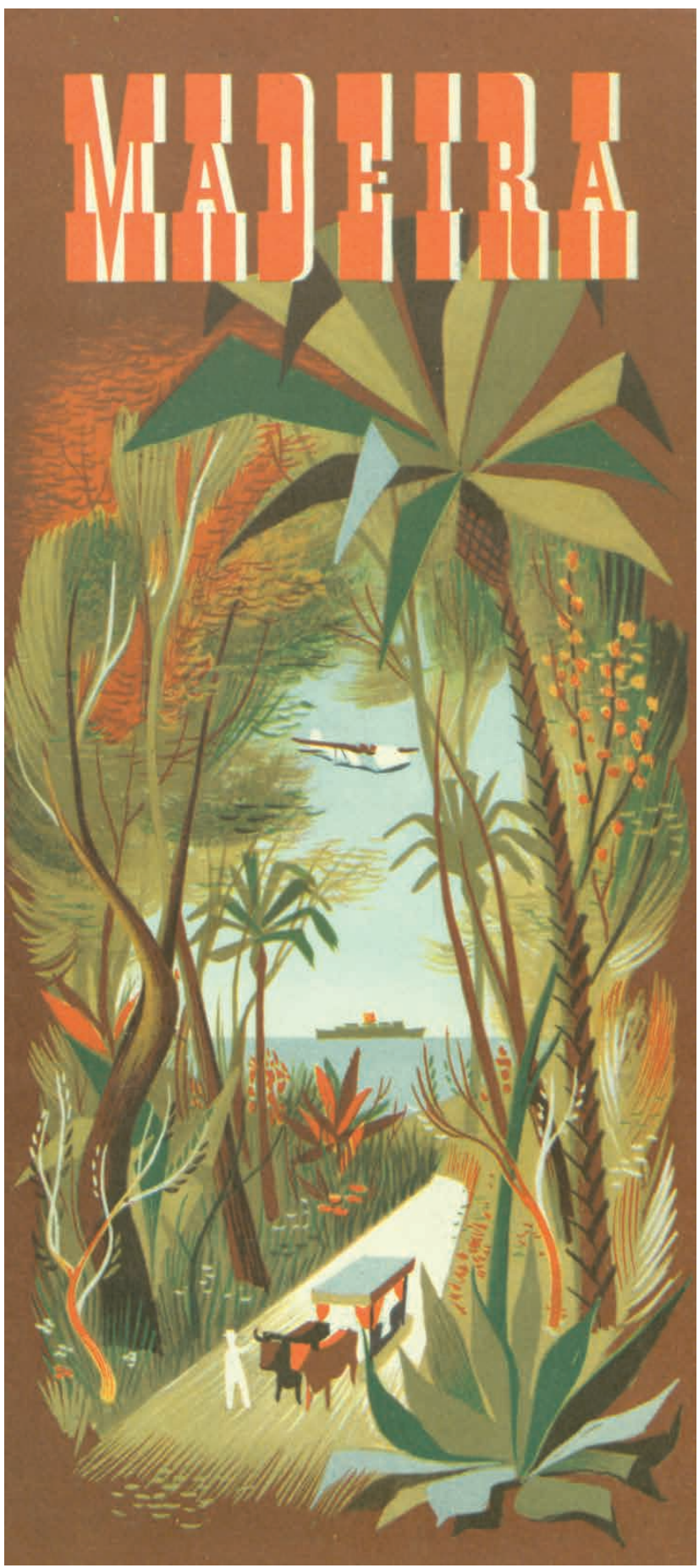

Figure 11: Leaflet $(30 \times 40 \mathrm{~cm})$ published in the sixties. Provider: Documentation Centre of the Estoril Higher School of Hospitality and Tourism 
Even though the increase of flight transportation was the most significant, during these decades, we may still find the permanence of the cruise ship as an element of the promotional imagery, usually as background, with a clear dominance of natural elements that make up the landscape scenery portrayed, with particular emphasis on palm trees, a key icon of tropicality (Figures 13 and 14).

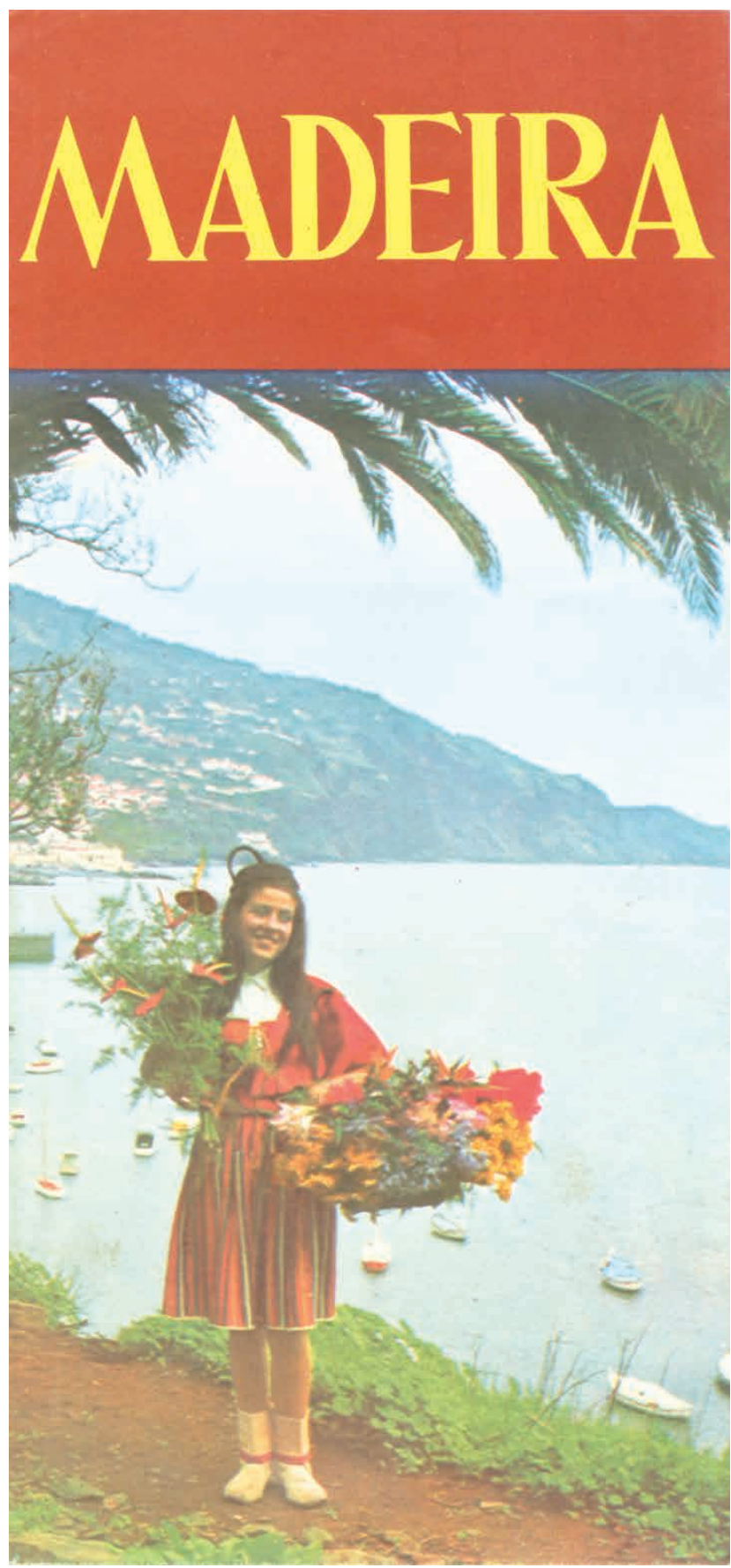

Figure 12: Leaflet $(32 \times 49 \mathrm{~cm})$ published in the seventies. Provider: Documentation Centre of the Estoril Higher School of Hospitality and Tourism
This late imagery, without destination name or slogan associated, could be easily compared to many other tropical wonderlands, easily observable in the illustrations and photographs used in tourism promotion of destinations such as Florida, the Antilles, among others.

\subsection{Blossoming of the Garden, Sprouting of Nature}

With the revolution in Portuguese political life in 1974, when Portugal became a democratic country after 48 years of dictatorship, the Madeira Archipelago became an Autonomous Region. It then happened to be a redefinition of the island's importance as a tourist destination. Road and port infrastructures were improved and built, communications modernized, hotel capacity substantially increased, and in 1980, a free trade and industry zone was created.

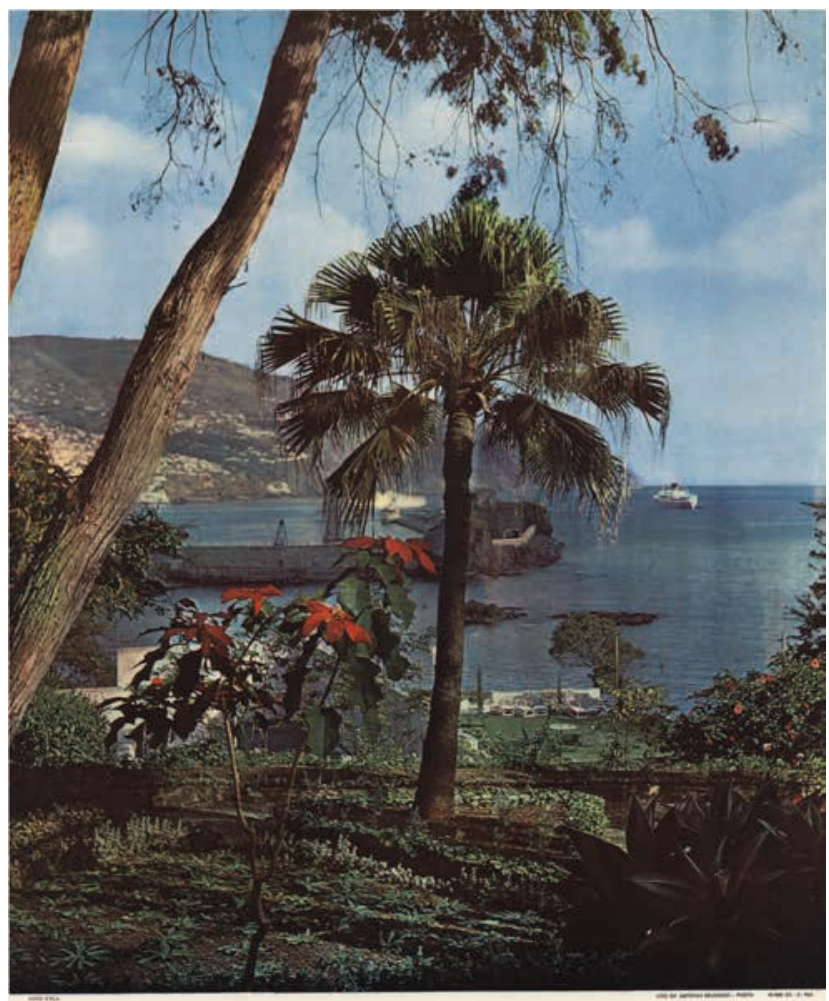

\section{Madeira}

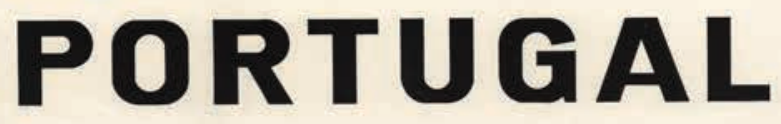

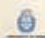

Figure 13: Poster $(100 \times 65 \mathrm{~cm})$ published in the sixties. Provider: National Library of Portugal 
It was the time for the Floating Garden slogan (Figures 15 and 16), in use between 1978 (establishment of the Regional Secretary of Tourism) and 1984, intended to display beautiful scenery and variety of flowers for which Madeira was known over the years (Jasper \& Schön in Carvalho, 2016, p. 34).

Madeira became defined as a tourist destination where tourists seek rest, natural beauty, pleasant climate staying, generally in mid-range hotels. It has always been promoted and advertised as an all-year destination where it is easy to find a vast diversity of activities including sports, leisure activities and characteristic animation (New Year's Eve celebrations with its renowned fireworks display, Carnival, Flower Festival, Wine Festival, amongst others).

In addition to the mild climate and the friendliness and hospitality of the people, in terms of natural tourism resources, Madeira Island has a rich and diverse vegetal heritage, multiple flower species as well as highly valued

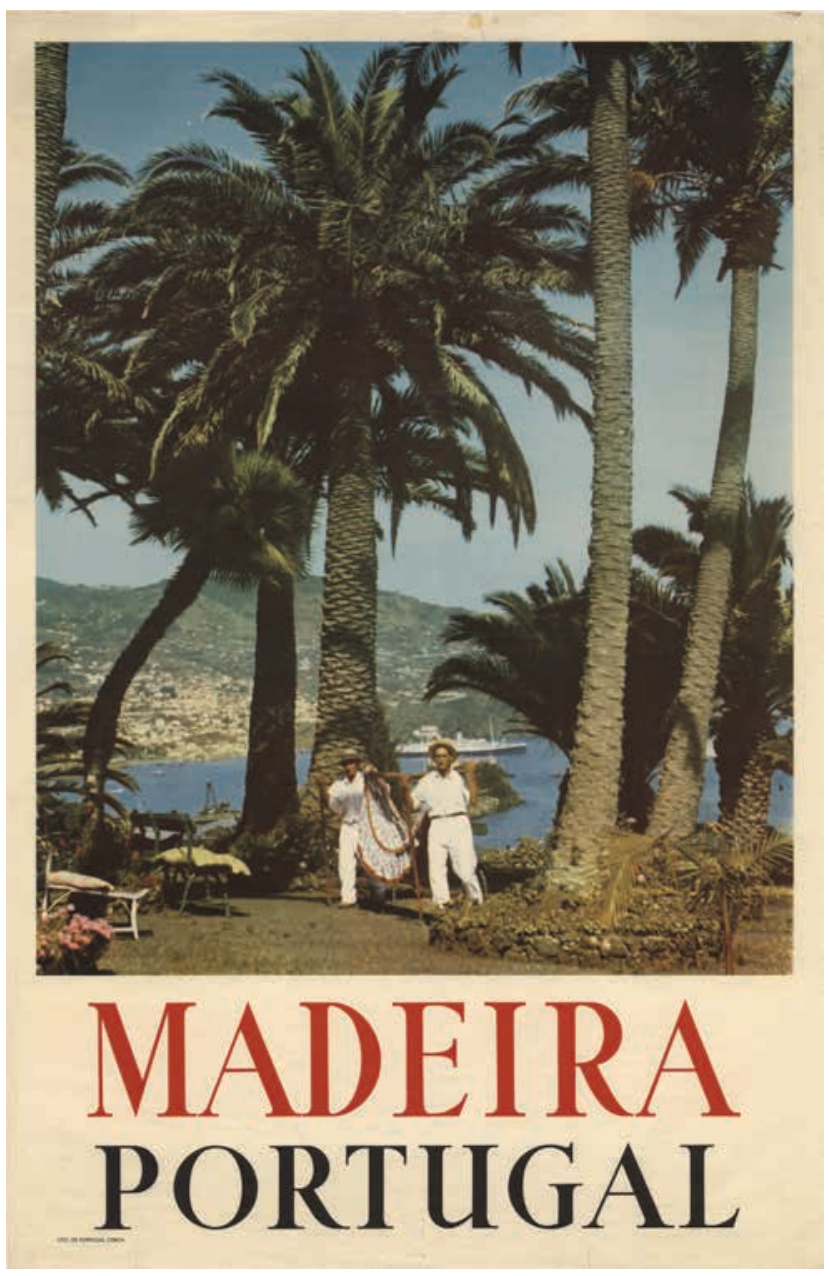

Figure 14: Poster $(100 \times 65 \mathrm{~cm})$ published in the sixties. Provider: National Library of Portugal regional products such as wine, sugar cane and the subtropical fruits. The chosen illustrations (Figure 17) for the commemorative envelopes and stamps edited by the Portuguese postal service (C.T.T.) to celebrate the World Tourism Conference held in Manila (Philippines) in 1980, clearly demonstrate the main elements that have been privileged in the tourist imagery of the destination

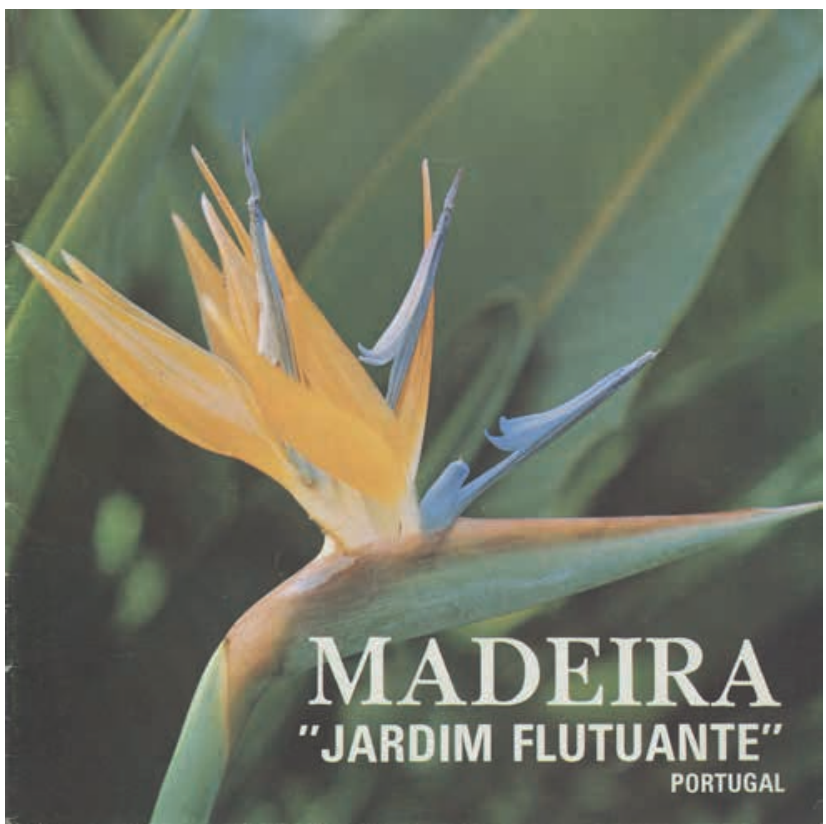

Figure 15: Brochure $(20 \times 20 \mathrm{~cm})$ published in the seventies. Provider: Documentation Centre of the Estoril Higher School of Hospitality and Tourism

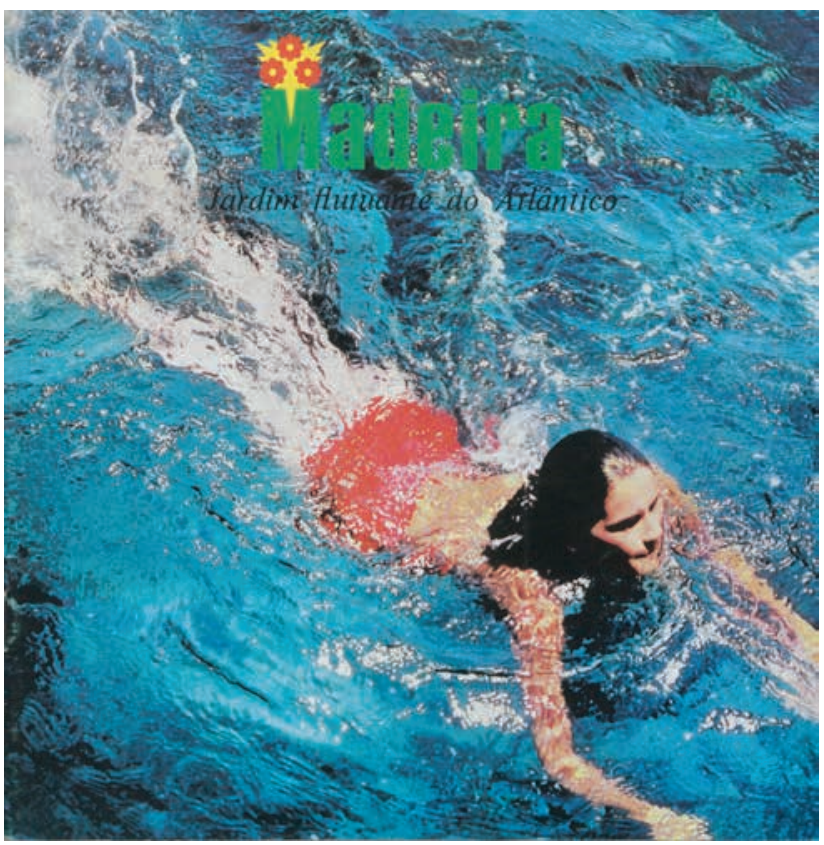

Figure 16: Brochure $(20 \times 20 \mathrm{~cm})$ published in the eighties. Provider: Documentation Centre of the Estoril Higher School of Hospitality and Tourism 
Madeira (Madeira wine, embroidery, flowers, fruit, traditional transports such as ox carts and traditional wooden craft, regional costumes and dances).

However, the famous 'Pearl of the Atlantic', as it became to be known, recommended in Europe as a wellknown climate-healing resort from the eighteenth and early nineteenth centuries, has been like others, reconverting, forgetting here and beyond, its therapeutic origins (Pina, 1988, p. 12).

Once more, TAP Air Portugal allows us to grasp another example (Figures 18 and 19), more recent in time, that confirms the previously mentioned association of transport companies with the editorial responsibility or sponsorship of the representational imagery of Madeira. The airline company was aiming to pick up at least a part of the visitors convinced by that promotion materials to have bought the experience of visiting the island, using TAP for their transportation.

Resulting from the blend of two imageries, since the 1980s, Madeira has been losing the connotation of health resort and has won one of a vacation Island (Câmara, 2002 in Carvalho, 2016, p. 33).

Between 1984 and 1993 Madeira used the slogan ' ... A different way to enjoy the sun!' (Figure 20). It was known not to be 'just a tropical island'. Its history, geography, climate, topography, traditions, infrastructure and people are profoundly different from the competitors', while the logo inspires a combination of tradition and modernity. The sun and the seagulls suggest vacations (Mc Cann-Erickson, in Carvalho, 2016, p. 34).

The endemic Laurissilva forest is a World Heritage Site since 1999 and is part of the European Biogenetic Reserves Network. This classification was just another leverage for the previously adopted tourist discourse where nature is
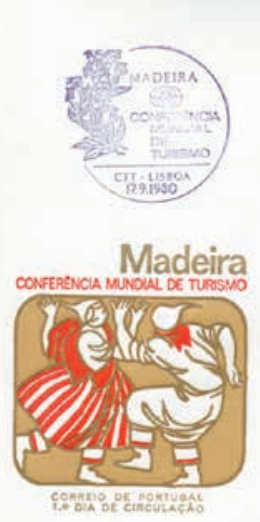

Figure 17: Commemorative First Day Cover envelope and stamps of the World Tourism Conference (Manila, 1980). Provider: Documentation Centre of the Estoril Higher School of Hospitality and Tourism central to the communication strategy, that will shape much of the promotional imagery of Madeira's destination from the end of the twentieth century onwards.

Between 1993 and 2002, Madeira's institutional promotional communication relished on the slogan 'Feel the nature around you' (Figure 21), crossed by the use of two

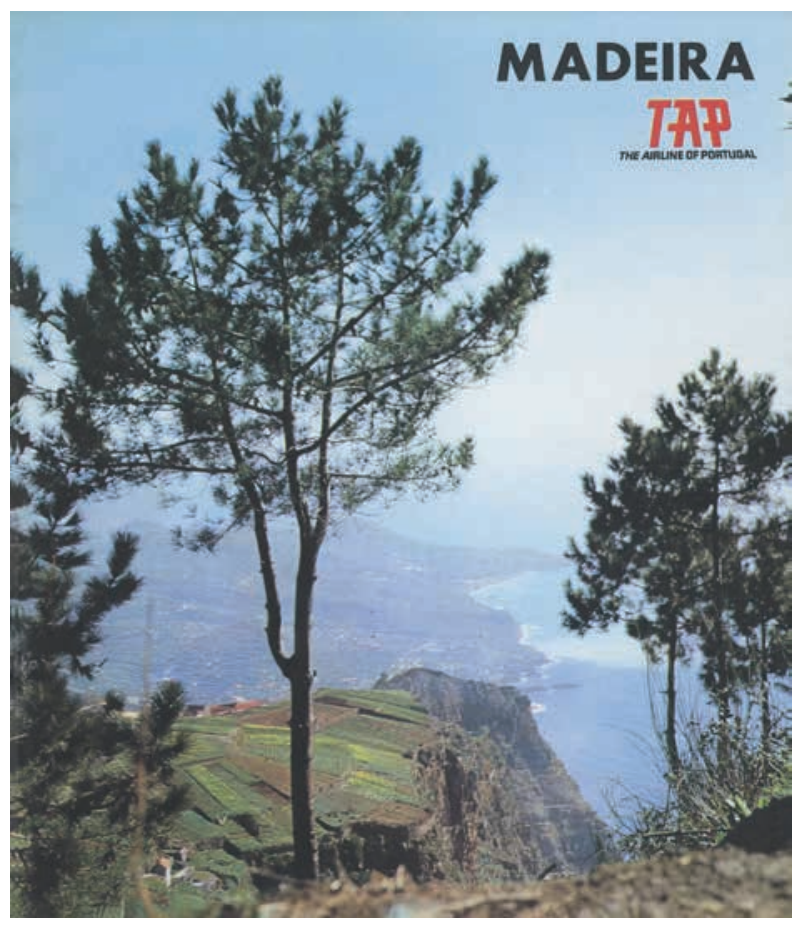

Figure 18: Brochure $(23$ x $20 \mathrm{~cm})$ published in 1973. Provider: Documentation Centre of the Estoril Higher School of Hospitality and Tourism

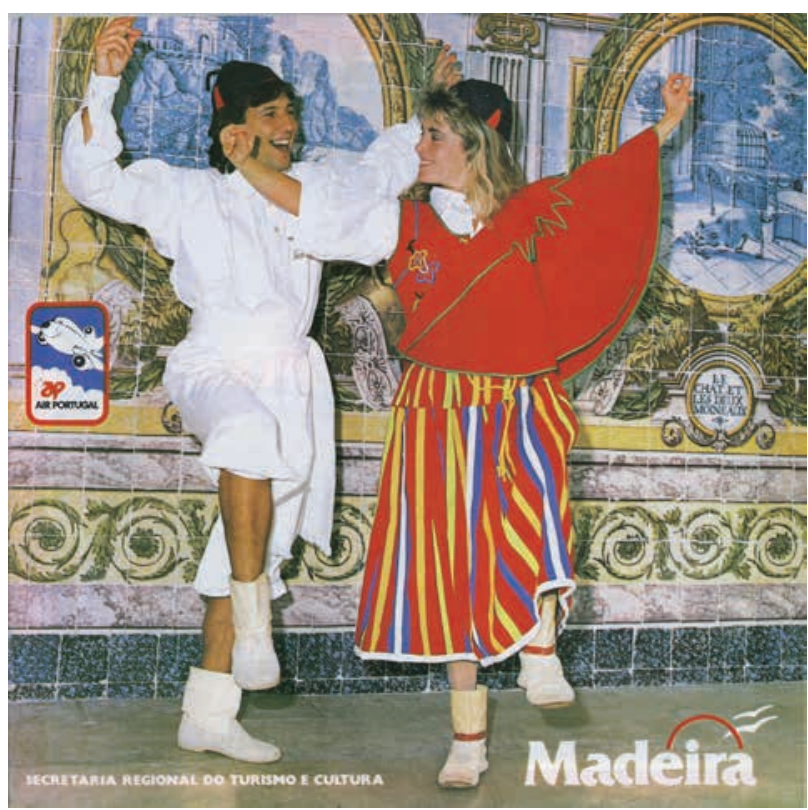

Figure 19: Brochure $(20 \times 21 \mathrm{~cm})$ published in 1988. Provider: Documentation Centre of the Estoril Higher School of Hospitality and Tourism 


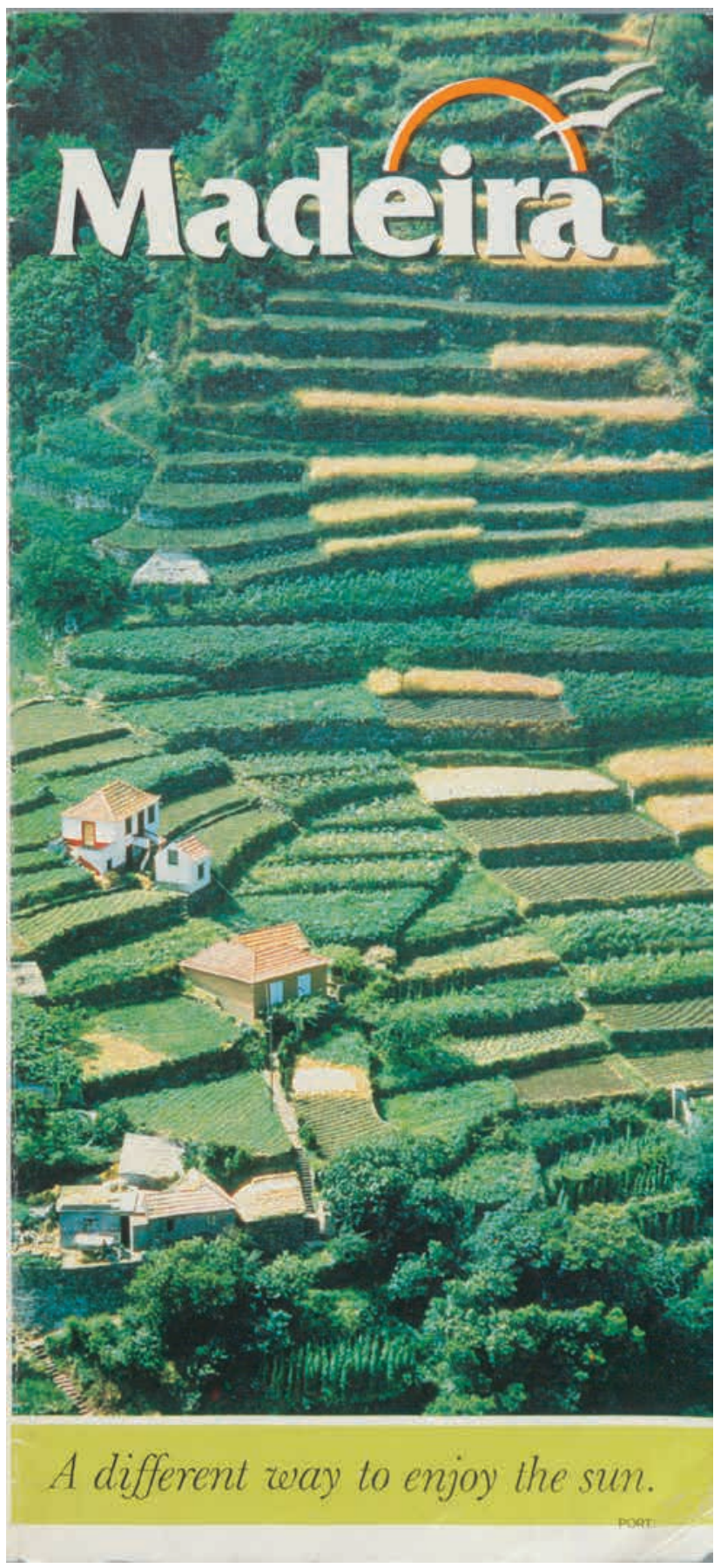

Figure 20: Leaflet $(22 \times 40 \mathrm{~cm})$ published in the eighties. Provider: Documentation Centre of the Estoril Higher School of Hospitality and Tourism

different logos that focused on the sun (1993-2002) and later on the island relief profile image (2002-2004).

This new slogan seemed to focus on the reinforcement of conveying the message of a call for a sustainable development of tourism, where attention and action are mesmerized by nature and landscape in what is the beginning of a world trend demand that we would see strongly strengthened within the concept of Nature Tourism. This

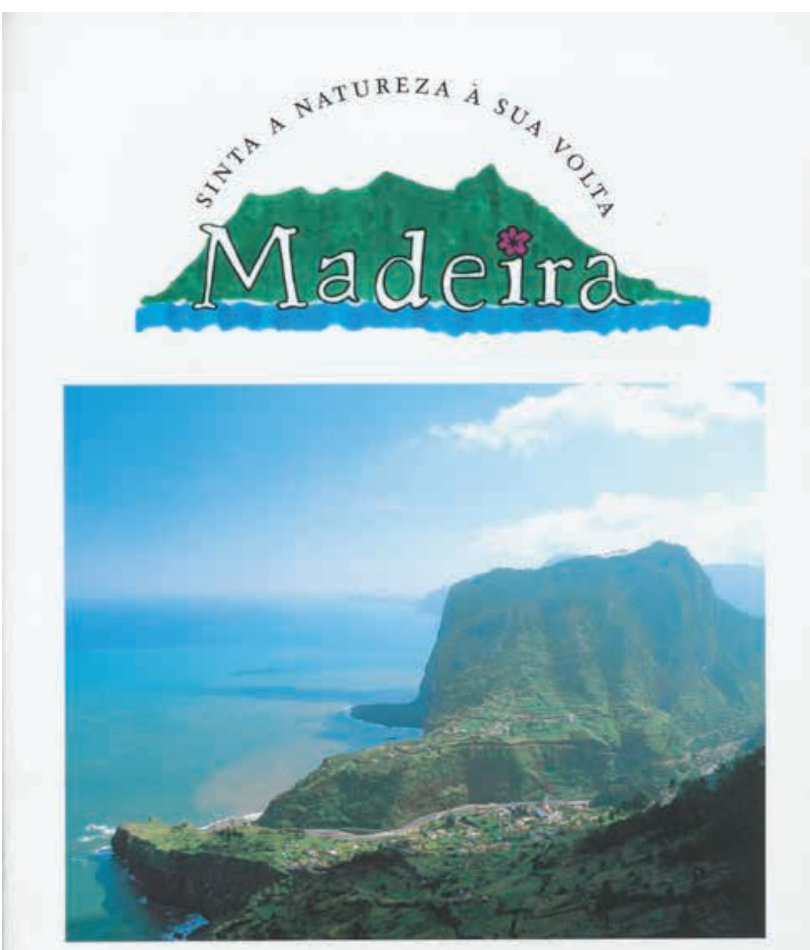

Figure 21: Brochure $(30 \mathrm{~cm})$ published in the nineties. Provider: Documentation Centre of the Estoril Higher School of Hospitality and Tourism

new nature-bound destination imagery displays now a much less tropical and much more native kind of natural landscape.

\section{Discussion}

The analysis and interpretation that we made of the evolution of the history of the tourist destination and representations in Madeira attempts to show the visual and textual elements that are fundamental for the construction of the destination tourist imagery. It is possible to find natural and cultural elements that were constant in the image, but also to find the characteristics that were making a difference in the tourism promotional message server at different times. The qualitative approach chosen by the authors was due to the reduced sample of available digital objects. The main goal is to show how their availability in an aggregate and free manner may well benefit tourism research.

Soon, the database should watch the increase in the available amount and diversity of objects, collections and content providers. It is essential to have other part- 
ners in order to augment the number of digital objects. All the players must play a role in the preservation, housing and accessibility needed for tourism history preservation. Just a reliable and dedicated effort of a network of entities (museums, libraries, archives, schools, hotels, travel agencies and others) devoted to the mission will allow a real valuable growth of this online platform contents, from what truly depends on its future development. Tourism has taken on such proportions that it is no longer possible for modern historians to ignore its importance as a strategic sector of economic development and as a notorious agent of social change. It, therefore, demands from all of us an approach following its relevance on the national and international scene. Sometimes, tourism history is just in the memory of people, and that too deserves to be attended on a testimonial database.

\section{Conclusions}

Portuguese tourism is a valuable heritage that demands from us all the utmost commitment in its collection and preservation, and we should all attend when Pina (1991, p. 13) warns us not to destroy what is left of the tourist past without prior consultation. This reality surely extends to other destinations.

The MUVITUR's database is in continuous and steady growth, due to the rise in number and diversity of content providers with its collections. This situation reminds us that the results and consequent interpretations we may do today may require revision and reanalysis in the future, as a result of the growing number of incorporated records.

Regardless, we think we can affirm that an in-depth study supported by a significant sample of documents that served to promote a destination, available at a single database, like the ones we just presented, can certainly soon constitute a significant value for the study of tourism history.

In this age of open data, open-source and shared platforms, it makes even more sense to develop an open hub for tourism research resources and contents to give all the tourism history lovers - these being stakeholders, agents, teachers, researchers or mere tourists - the possibility not to forget the history of tourism.

We dare to say that we have now even more reasons to be concerned with finding ways to gather evidence of tourism activities. We are watching a whole new era of virtual materials produced and discarded from the online world without any concerns with their preservation and even fewer chances for their recovery for historical pur- poses. The threat to the availability of historical evidence and the actual context of technological developments makes the efforts to develop further the Virtual Museum of Tourism more and more relevant.

\section{References}

[1] Aurindo, M. J., \& Machado, C. (2016). MUVITUR® (virtual museum of tourism): A new approach to tourism history. Journal of Tourism History, 8(3), 300-309. https://doi. org/10/gf86hf

[2] Baptista, J. M. de L. (2005). Evolução do turismo na Madeira no período 1975 a 2000. Funchal: [s.n.].

[3] Blain, C., Levy, S. E., \& Ritchie, J. R. B. (2005). Destination Branding: Insights and Practices from Destination Management Organizations. Journal of Travel Research, 43(4), 328-338. https://doi.org/10/bt2twg

[4] Branco, A. F. (1936). O Turismo na Madeira. 3-6. Lisboa: [s.n.]

[5] Carvalho, T. F. F. (2016). A importância da Marca no contexto turístico da Madeira (Dissertação de Mestrado em Ciências da comunicação, marketing e publicidade, Universidade Lusófona). Available at http://hdl.handle.net/10437/7645

[6] Crouch, D., \& Lübbren, N. (2003). Visual Culture and Tourism. Bloomsbury Academic.

[7] Dann, G. (1996). The language of tourism: A sociolinguistic perspective. $\mathrm{CAB}$ International.

[8] Evans, J., \& Hall, S. (1999). Visual Culture: The Reader. SAGE Publications in association with the Open University.

[9] Gallarza, M. G., Saura, I. G., \& García, H. C. (2002). Destination image: Towards a Conceptual Framework. Annals of Tourism Research, 29(1), 56-78. https://doi.org/10/cdr2fx

[10] Jafari, J. (Ed.). (2000). Encyclopedia of Tourism. London; New York: Routledge.

[11] Koebel, W. H. (William H. (1909). Madeira: Old and new. Obtido de http://archive.org/details/madeiraoldnew00koebuoft

[12] Paulino, F. F., \& Silva, Susana. (2000). Aeroporto da Madeira: A história de um sonho. Lisboa: Edicarte.

[13] Pike, S. (2002). Destination image analysis-A review of 142 papers from 1973 to 2000. Tourism Management, 23(5), 541-549. https://doi.org/10/dgztdx

[14] Pina, P. (1988). Portugal: O turismo no século XX. Lisboa: Lucidus.

[15] Pina, P. (1991). Na fronteira de um novo mundo (1170-1850). Turismo: Boletim da DGT, (24-26), 4-43.

[16] Salazar, N. B. (2016). Imaginary in Jafari, J., \& Xiao, H., Encyclopedia of Tourism. Switzerland: Springer, p. 500, 456-457

[17] Salazar, N. B. (2012). Tourism Imaginaries: A Conceptual Approach. Annals of Tourism Research, 39(2), 863-882. https://doi.org/10/b5w2px

[18] Silva, I. (Ed.). (1985). A Madeira e o turismo: Pequeno esboço histórico. Funchal: Secretaria Regional do Turismo e Cultura, Direcção Regional dos Assuntos Culturais, Centro de Apoio às Ciências Históricas.

[19] Urry, J. (1995). Consuming Places. Taylor \& Francis.

[20] Urry, J. (2002). The Tourist Gaze. SAGE Publications. 